\title{
PENGARUH PEMBERIAN JUS DAUN UBI JALAR (Ipomoea batatas $($ L.) Lam) TERHADAP KADAR KOLESTEROL LDL TIKUS WISTAR JANTAN (Rattus norvegicus) YANG DIBERI PAKAN TINGGI LEMAK
}

\author{
Rani Pramesti, Nurmasari Widyastuti* \\ Program Studi Ilmu Gizi Fakultas Kedokteran Universitas Diponegoro \\ Jl.Dr.Sutomo No.18, Semarang, Telp (024) 8453708, Email : gizifk@ undip.ac.id
}

\begin{abstract}
Background: Oxidative stress is accompanied by an increase in cholesterol levels, it will trigger LDL oxidation that make inflammation getting worse and atherosclerosis that can lead to coronary heart disease (CHD). Flavonoids can improve vascular endothelial function, reduce LDL sensitivity to the effects of free radicals, are lowering blood lipid levels, and as an anti-inflammatory. One of the vegetables that contain flavonoids such as quercetin, which can be used are the leaves of sweet potato (Ipomoea batatas (L.) Lam). This study aims to determine the effects of sweet potato leaves juice (Ipomoea batatas (L.) Lam) to LDL cholesterol levels in male Wistar rats (Rattus norvegicus) fed with a high fat diet.

Methods: This study was a true experimental research pre-post test control group design with 12 Wistar rats (Rattus norvegicus) were divided into two groups. At the time of the intervention, both groups received standard feed BR-2 as much as $12 \mathrm{mg} / 200 \mathrm{~g}$ weight/day. The control group was fed only the standard, the treatment group were given sweet potato leaves juice with a dose of $0.006 \mathrm{ml} / \mathrm{g}$ weight/day for 14 days. Measurement of serum LDL cholesterol were conducted three times, after acclimatization, after high-fat feeding and after given sweet potato leaves juice. Serum LDL cholesterol checked using the CHOD-PAP method. Data were analyzed by paired t-test, independen t-test, Wilcoxon and Mann Whitney.

Result: LDL cholesterol levels in the treatment group showed that there were 4 mice decreased, a mean decreased of $5: 44 \mathrm{mg} / \mathrm{dl}$ whereas in the control group that there were 4 mice increased, a mean increased of $4.79 \mathrm{mg} / \mathrm{dl}$. There was no significant difference ( $p>0.05)$ changed in LDL cholesterol levels between groups.

Conclusion: Giving sweet potato leaves juice (Ipomoea batatas (L.) Lam) of $0.006 \mathrm{ml} / \mathrm{g}$ weight/day for 14 days can not lower LDL cholesterol levels of male Wistar rats (Rattus norvegicus) fed a high fat diet

Keywords: sweet potato leaves juice; LDL cholesterol; high fat diet
\end{abstract}

\begin{abstract}
ABSTRAK
Latar Belakang: Stres oksidatif yang disertai dengan peningkatan kadar kolesterol, akan memicu oksidasi LDL yang akan memperburuk inflamasi dan aterosklerosis sehingga dapat menyebabkan Penyakit Jantung Koroner (PJK). Flavonoid dapat memperbaiki fungsi endotel pembuluh darah, mengurangi kepekaan LDL terhadap pengaruh radikal bebas dan dapat menurunkan kadar lipid darah. Salah satu sayuran yang mengandung flavonoid berupa quercetin yang bisa dimanfaatkan adalah daun ubi jalar (Ipomoea batatas (L.) Lam). Penelitian ini bertujuan untuk mengetahui pengaruh pemberian jus daun ubi jalar (Ipomoea batatas (L.) Lam) terhadap kadar kolesterol LDL tikus wistar jantan (Rattus norvegicus) yang diberi pakan tinggi lemak.

Metode: Penelitian ini merupakan penelitian true eksperimental dengan rancangan penelitian pre-post test with control group design dengan 12 ekor tikus Wistar (Rattus norvegicus) yang dibagi menjadi dua kelompok. Pada saat intervensi, kedua kelompok mendapatkan pakan standar BR-2 sebanyak 12 mg/200grBB/hari. Kelompok kontrol hanya diberi pakan standar dan kelompok perlakuan diberi jus daun ubi jalar dengan dosis $0.006 \mathrm{ml} / \mathrm{grBB} / \mathrm{hari}$ selama 14 hari. Pengukuran serum kolesterol LDL dilakukan sebanyak tiga kali yaitu setelah aklimatisasi, setelah pemberian pakan tinggi lemak dan setelah pemberian jus daun ubi jalar. Cara pengukuran dengan metode pemeriksaan CHOD-PAP. Data dianalisis dengan uji Paired t-test, Independen t-test, Wilcoxon dan Mann Whitney. Hasil: Kadar kolesterol LDL pada kelompok perlakuan menunjukkan sebanyak 4 tikus mengalami penurunan, rerata penurunan sebesar $5.44 \mathrm{mg} / \mathrm{dl}$ sedangkan pada kelompok kontrol sebanyak 4 tikus mengalami peningkatan, rerata peningkatan sebesar $4.79 \mathrm{mg} / \mathrm{dl}$. Tidak ada perbedaan yang signifikan $(p>0.05)$ pada perubahan kadar kolesterol LDL antar kelompok.

Kesimpulan: Pemberian jus daun ubi jalar (Ipomoea batatas (L.) Lam) sebanyak 0,006 ml/grBB/hari selama 14 hari tidak dapat menurunkan kadar kolesterol LDL tikus Wistar jantan (Rattus norvegicus) yang diberi pakan tinggi lemak Kata kunci : jus daun ubi jalar; kolesterol LDL; pakan tinggi lemak
\end{abstract}

\section{PENDAHULUAN}

Stres oksidatif yang disertai peningkatan kadar kolesterol, akan oksidasi LDL yang akan memperburuk inflamasi dengan dan aterosklerosis sehingga dapat menyebabkan memicu Penyakit Jantung Koroner (PJK). ${ }^{1,2}$ Di Indonesia 
pada tahun 2006, PJK merupakan penyebab utama dari seluruh kematian, dimana prevalensinya adalah $26,4 \% .{ }^{3}$ Berdasarkan profil kesehatan provinsi Jawa Tengah pada tahun 2012, prevalensi PJK sebanyak 554.771 kasus $(67,57 \%)$ lebih rendah dibanding tahun 2011, yaitu sebanyak 634.860 kasus $(72,13 \%) .{ }^{4}$ Salah satu faktor risiko untuk penyakit aterosklerosis yaitu kolesterol LDL yang tinggi. ${ }^{5}$ LDL yang teroksidasi akan meningkat dan mengendap di pembuluh darah jantung sehingga menyebabkan pembuluh darah menjadi sempit dan aliran darah terganggu. Semakin tinggi LDL yang teroksidasi maka dinding pembuluh darah akan semakin tebal sehingga dapat merusak endhotel. Salah satu upaya untuk mencegah LDL teroksidasi oleh radikal bebas adalah dengan meningkatkan asupan antioksidan. ${ }^{2}$

Antioksidan adalah senyawa yang dapat menetralkan radikal bebas. Antioksidan salah satunya terdiri dari senyawa fenolik antara lain polifenol dan flavonoid. Bahan makanan yang mengandung flavonoid seperti sayur-sayuran, buahbuahan, dan umbi-umbian dapat mencegah berbagai penyakit yang berkaitan dengan stress oksidatif. Flavonoid dapat memperbaiki fungsi endotel pembuluh darah, dapat mengurangi kepekaan LDL terhadap pengaruh radikal bebas dan bersifat menurunkan kadar lipid darah. Salah satu sayuran sumber flavonoid yang bisa dimanfaatkan adalah daun ubi jalar (Ipomoea batatas (L.) Lam). ${ }^{1,6}$

Flavonoid merupakan salah satu kelompok fitokimia yang memiliki struktur yang sama, yaitu polifenol. Banyak penelitian yang menyatakan bahwa flavonoid ini dapat menurunkan faktor risiko penyakit kardiovaskular karena berperan dalam metabolisme lipid. ${ }^{7}$ Daun ubi jalar lebih banyak mengandung polifenol dibandingkan dengan umbinya, juga banyak mengandung vitamin dan mineral. ${ }^{8}$ Flavonoid yang banyak terdapat dalam daun ubi jalar yaitu quercetin. Quercetin memiliki efek antioksidan yang dapat menangkal radikal bebas sehingga dapat terlindungi dari kerusakan oksidatif. Pada suatu penelitian quercetin murni pada dosis $2 \mathrm{mg} / \mathrm{kgBB}$ dapat menurunkan konsentrasi serum kolesterol total, LDL dan trigliserida. ${ }^{9,10}$ Pada penelitian sebelumnya, ekstrak air dari daun ubi jalar ungu dapat memperbaiki profil lipid darah tikus putih yang diberikan makanan tinggi kolesterol dengan dosis $3 \mathrm{cc}$ pagi dan 33 cc sore selama 3 bulan. ${ }^{1}$

Penelitian ini menggunakan tikus putih jantan dengan galur Wistar karena dapat memberikan hasil penelitian yang lebih stabil karena tidak dipengaruhi adanya siklus estrus dan kehamilan. Tikus juga lebih mudah dikontrol dari asupan makanan dan aktivitas fisik sehingga memperkecil terjadinya bias saat penelitian. Pemilihan galur Wistar dikarenakan galur tersebut sensitif terhadap diet lemak. ${ }^{11}$ Penelitian ini bertujuan untuk mengetahui pengaruh pemberian jus daun ubi jalar (Ipomoea batatas $(L$.) Lam) terhadap kadar kolesterol LDL tikus wistar jantan (Rattus norvegicus) yang diberi pakan tinggi lemak.

\section{METODE PENELITIAN}

Penelitian ini merupakan penelitian dengan pendekatan true eksperimental dengan rancangan penelitian pre-post test with control group design. Penelitian dilakukan pada bulan Juni 2014 hingga Juli 2014. Variabel bebas dalam penelitian ini adalah pemberian jus daun ubi jalar, sementara variabel terikatnya adalah kadar kolesterol LDL. Subyek penelitian menggunakan tikus galur wistar jantan, dengan kriteria inklusi yaitu berat badan sebesar 150 - 200 gram pada umur $8-12$ minggu dan kriteria eksklusi yaitu tikus mengalami penurunan berat badan sebesar $10 \%$ dari berat badan per minggu, tikus mengalami perubahan perilaku (sakit dan kehilangan nafsu makan) dan tikus mati saat penelitian berlangsung.

Tikus diperoleh dan ditempatkan di Laboratorium Fisiologi Hewan Jurusan Biologi, FMIPA, UNNES. Penentuan jumlah subyek menggunakan ketentuan WHO, dimana jumlah minimal subjek penelitian per kelompok adalah 5 ekor. ${ }^{12}$ Pada penelitian ini terdapat 2 kelompok, untuk mengantisipasi terjadinya drop out, maka jumlah subyek ditambah 1 ekor tiap kelompok, sehingga masing-masing kelompok terdiri atas 6 ekor tikus, jadi keseluruhan jumlah sampel yang dibutuhkan adalah 12 ekor. Dibagi 2 kelompok perlakuan yaitu : Kelompok kontrol (K) yaitu tikus yang diberi pakan tinggi lemak saja tanpa diberi jus daun ubi jalar dan kelompok perlakuan $(\mathrm{P})$ yaitu tikus yang diberi pakan tinggi lemak dan diberi jus daun ubi jalar sebanyak $0,006 \mathrm{ml} / \mathrm{gBB} /$ hari.

Bahan yang digunakan dalam penelitian ini meliputi pakan standar, pakan tinggi lemak, dan jus daun ubi jalar. Pakan standar yang digunakan adalah pakan jenis BR-2 yang mengandung protein kasar $19 \%$ dan lemak kasar 5\% sebanyak $12 \mathrm{~g} / 200 \mathrm{gBB} /$ hari $^{13}$, sedangkan pakan tinggi lemak yang digunakan yaitu kuning telur bebek yang mengandung 17 gram protein, 35 gram lemak, 884 $\mathrm{mg} / 100$ gr kolesterol sebanyak $2 \mathrm{ml} / 200 \mathrm{gBB} / \mathrm{hari}$ yang diberikan dengan cara disonde. ${ }^{14,15}$ Penentuan dosis jus daun ubi jalar berdasarkan kadar quercetin 
yakni sebesar $2 \mathrm{mg} / \mathrm{kgBB} / \mathrm{hari}$ yang diberikan dengan cara disonde.

Pembuatan jus daun ubi jalar yaitu daun ubi jalar berumbi putih yang masih segar dan berwarna hijau disortasi, ditimbang 100 g kemudian dicuci hingga bersih pada air mengalir. Daun ubi jalar di rebus dengan air $100 \mathrm{ml}$ selama 5 menit dengan api sedang. Daun yang telah direbus ditambahkan dengan air rebusan yang tersisa kemudian diblender dengan kecepatan tinggi selama 15-20 detik. Penentuan dosis jus daun ubi jalar yang diberikan berdasarkan kandungan kadar quercetin dalam jus daun ubi jalar. Uji kandungan quercetin jus daun ubi jalar dilakukan di Laboratorium Teknologi Pangan Universitas Katholik Soegijapranata dengan metode spektofotometri. Jus daun ubi jalar ditimbang terlebih dahulu, penimbangan dilakukan agar jus homogen, kemudian dilakukan analisis quercetin yaitu larutan encer $(1 \mathrm{ml})$ yang mengandung flavonoid, $5 \%(\mathrm{w} / \mathrm{w}) \mathrm{NaNO}_{2}(0,7 \mathrm{ml})$ dan $30 \%(\mathrm{v} / \mathrm{v})$ etanol $(10 \mathrm{ml})$ dikocok selama 5 menit, kemudian ditambahkan $10 \% \mathrm{AlCl}_{3}$ (w/w 0,7 ml) lalu semua bahan dikocok selama 6 menit. Setelah 6 menit, tambahkan $1 \mathrm{~mol} / \mathrm{L} \mathrm{NaOH}(5 \mathrm{ml})$. Larutan tersebut kemudian dilarutkan ke dalam $25 \mathrm{ml}$ etanol $30 \%$ $(\mathrm{v} / \mathrm{v})$. Setelah didiamkan selama 10 menit, absorbansi larutan diukur menggunakan spektofotometer. Curva standar diplot menggunakan quercetin sebagai standar. Perbedaan konsentrasi quercetin menggunakan $80 \%$ etanol dan absorbansinya dihitung pada $430 \mathrm{~nm}$ menggunakan spektofotometer. Hasilnya menunjukkan mg quercetin/g berat kering. Setelah dilakukan analisis, diperoleh hasil dalam $100 \mathrm{ml}$ jus daun ubi jalar mengandung sebanyak 32,296 mg quercetin, sehingga dosis jus daun ubi jalar untuk perlakuan pada tikus yaitu sebesar $0,006 \mathrm{ml} / \mathrm{gBB} /$ hari. $^{16}$

Kedua kelompok ditimbang berat badannya setiap minggu untuk mengetahui perubahan berat badan tikus dengan tujuan untuk penentuan pemberian pakan standar dan dosis jus daun ubi jalar. Pengambilan darah dilakukan sebanyak tiga kali yaitu setelah aklimatisasi, setelah pemberian pakan tinggi lemak dan setelah pemberian jus daun ubi jalar. Sebelum diambil sampel darahnya tikus dipuasakan selama 12 jam, selanjutnya sampel darah diambil sebanyak $2 \mathrm{ml}$ melalui pleksus retroorbitalis. Cara pengukuran dengan metode pemeriksaan menggunakan Cholesterol Oxsidase Phenol Aminophenazone (CHOD-PAP) dengan prinsip spektrofotometri enzimatis. ${ }^{17}$

Seluruh data hasil kadar kolesterol LDL tikus diuji normalitas dengan uji Saphiro-Wilk. Perbedaan kadar kolesterol LDL sebelum dan sesudah perlakuan di uji dengan paired t-test jika distribusi data normal dan jika data tidak normal dilakukan uji Wilcoxon. Perbedaan pengaruh dari kedua kelompok perlakuan dianalisis dengan menggunakan uji independent t-test untuk data berdistribusi normal dan uji Mann-Whitney untuk data berdistribusi tidak normal. ${ }^{18}$

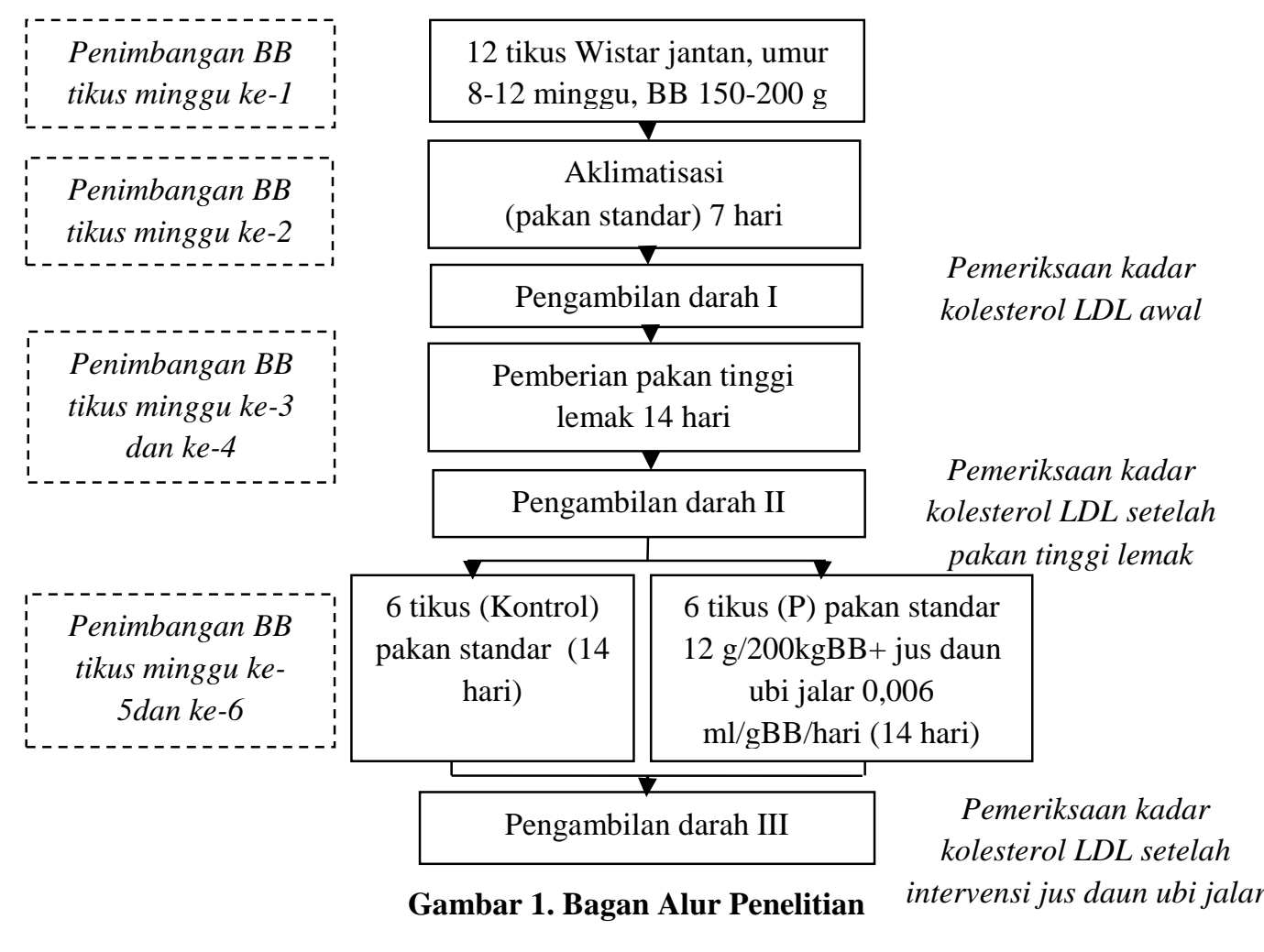


HASIL PENELITIAN

Berat Badan Tikus

Perubahan berat badan pada tikus wistar jantan

(Rattus norvegicus) pada kelompok kontrol dan perlakuan selama penelitian dapat dilihat pada gambar 1.

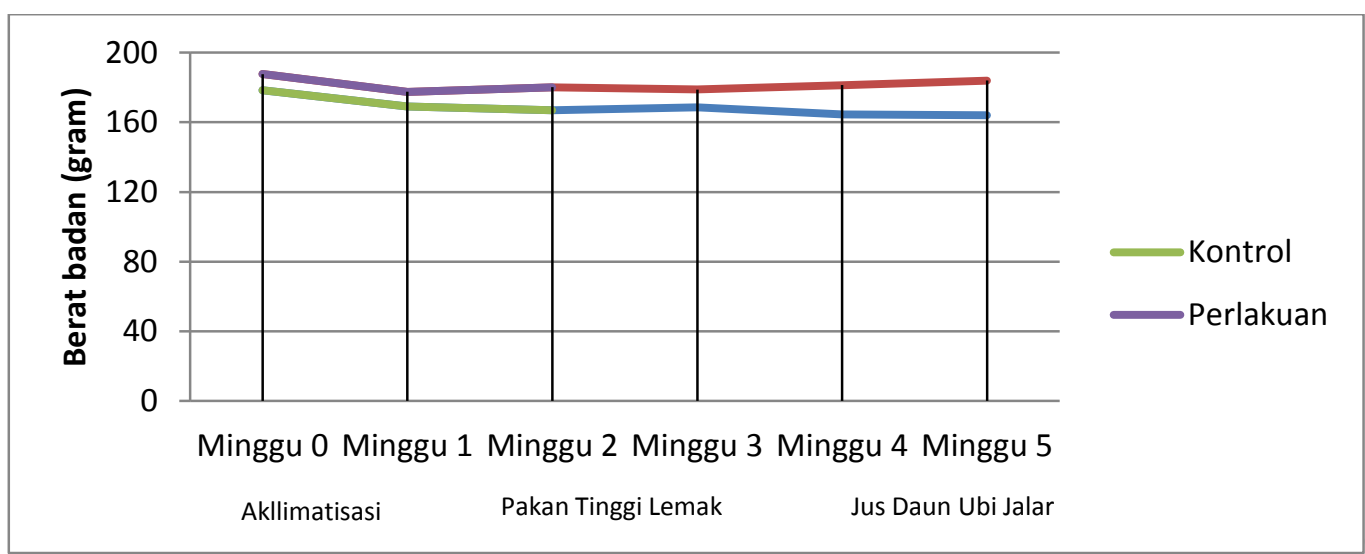

Perkembangan berat badan tikus wistar jantan

Gambar 2.

Berat badan tikus kedua kelompok sebelum dan sesudah pemberian pakan tinggi lemak dapat dilihat pada tabel 1 .

Tabel 1. Perbedaan Berat Badan Tikus Sebelum dan Sesudah Pemberian Pakan Tinggi Lemak selama 14 hari

\begin{tabular}{lccc}
\hline \multirow{2}{*}{ Variabel } & Kontrol $(\mathbf{n}=6)$ & Perlakuan $(\mathbf{n}=6)$ & \multirow{2}{*}{$\mathbf{p}^{\mathbf{b}}$} \\
\cline { 2 - 3 } & Mean \pm SD & Mean \pm SD & \\
\hline Berat Badan $(\mathbf{g})$ & $169.17 \pm 6.55$ & $177.50 \pm 7.40$ & \\
Sebelum & $168.67 \pm 9.11$ & $178.83 \pm 6.43$ & \\
Sesudah & $-0.50 \pm 3.94$ & $1.33 \pm 2.94$ & $0.382^{\mathrm{b}}$ \\
$\boldsymbol{\Delta}$ & $0.768^{\mathrm{a}}$ & $0.318^{\mathrm{a}}$ & \\
$\mathbf{P}$ & & & \\
\hline
\end{tabular}

Keterangan: ${ }^{a} \mathrm{Uji}$ Paired $t$-test

${ }^{\mathrm{b}} \mathrm{Uji}$ Independent t-test

Tabel 1 menunjukkan bahwa setelah pemberian pakan tinggi lemak pada kelompok kontrol terdapat penurunan berat badan namun tidak signifikan ( $>00.05)$. Pada kelompok perlakuan menunjukkan peningkatan berat badan namun tidak signifikan $(p>0.05)$. Rerata perubahan berat badan antar kelompok menunjukkan tidak ada perbedaan berat badan antara kelompok kontrol dan kelompok perlakuan yang diberi pakan tinggi lemak ( $p>0.05)$.

Berat badan tikus kedua kelompok sebelum dan sesudah pemberian jus daun ubi jalar dapat dilihat pada tabel 2 .

Tabel 2. Perbedaan Berat Badan Tikus Sebelum dan Sesudah Pemberian Jus Daun Ubi Jalar selama 14 hari

\begin{tabular}{lccc}
\hline \multirow{2}{*}{ Variabel } & Kontrol $(\mathbf{n}=6)$ & Perlakuan $(\mathbf{n = 6})$ & \multirow{2}{*}{$\mathbf{p}^{\mathbf{b}}$} \\
\cline { 2 - 3 } & Mean $\mathbf{\text { SD }}$ & Mean \pm SD & \\
\hline Berat Badan (g) & $168.67 \pm 9.11$ & $178.83 \pm 6.43$ & \\
Sebelum & $164.00 \pm 9.57$ & $184.00 \pm 5.83$ & \\
Sesudah & $-4.67 \pm .4 .76$ & $5.17 \pm 3.76$ & $0.003^{\mathrm{b}}$ \\
$\boldsymbol{\Delta}$ & $0.062^{\mathrm{a}}$ & $0.020^{\mathrm{a}}$ & \\
$\mathbf{P}$ & & & \\
\hline
\end{tabular}

Keterangan: ${ }^{a}$ Uji Paired t-test

${ }^{\mathrm{b}} \mathrm{Uji}$ Independent t-test

Tabel 2 menunjukkan bahwa pada kelompok kontrol yang hanya diberi pakan standar terdapat penurunan berat badan yang tidak signifikan (p>0.05). Pada kelompok perlakuan setelah 
pemberian jus daun ubi jalar menunjukkan terdapat peningkatan berat badan secara signifikan $(\mathrm{p}<0.05)$. Rerata perubahan berat badan antar kelompok menunjukkan terdapat perbedaan berat badan antara kelompok kontrol dan perlakuan yang diberi jus daun ubi jalar $(\mathrm{p}<0.05)$.

\section{Perubahan Kadar Kolesterol LDL Sebelum dan Sesudah Pemberian Pakan Tinggi Lemak}

Perubahan kadar kolesterol LDL sebelum dan sesudah pemberian pakan tinggi lemak masingmasing tikus dapat dilihat pada tabel 3 .

Tabel 3. Perubahan Kadar Kolesterol LDL Sebelum dan Sesudah Pemberian Pakan Tinggi Lemak

\begin{tabular}{cccc}
\hline Tikus & Kolesterol LDL Awal $(\mathbf{m g} / \mathbf{d l})$ & Kolesterol LDL PTL $(\mathbf{m g} / \mathbf{d l})$ & Ket $(\boldsymbol{\Delta})$ \\
\hline \hline K1 & 43.94 & 58.20 & naik \\
K2 & 40.61 & 47.97 & naik \\
K3 & 72.49 & 43.70 & turun \\
K4 & 31.85 & 49.76 & naik \\
K5 & 32.71 & 49.32 & naik \\
K6 & 77.97 & 51.08 & turun \\
P1 & 80.02 & 48.77 & turun \\
P2 & 45.89 & 67.70 & naik \\
P3 & 51.26 & 80.01 & naik \\
P4 & 30.41 & 50.26 & naik \\
P5 & 48.34 & 25.53 & turun \\
P6 & 50.02 & 57.56 & naik \\
\hline
\end{tabular}

Keterangan: $\quad \mathrm{K}=$ Kontrol $\quad \mathrm{P}=$ Perlakuan

Tabel 3 menunjukkan setelah pemberian pakan tinggi lemak berupa kuning telur bebek sebanyak 8 tikus (K1, K2, K4, K5, P2, P3, P4, P6) menunjukkan peningkatan kadar kolesterol LDL sedangkan sebanyak 4 tikus (K3, K6, P1, P5) mengalami penurunan kadar kolesterol LDL. Rerata kadar kolesterol LDL kedua kelompok sebelum dan sesudah pemberian pakan tinggi lemak dapat dilihat pada tabel 4 .

Tabel 4. Rata-rata Kadar Kolesterol LDL Sebelum dan Sesudah Pemberian Pakan Tinggi Lemak selama 14 hari

\begin{tabular}{lccc}
\hline \multirow{2}{*}{ Variabel } & Kontrol $(\mathbf{n}=\mathbf{6})$ & Perlakuan $(\mathbf{n}=\mathbf{6})$ & \multirow{2}{*}{$\mathbf{p}^{\mathbf{b}}$} \\
\cline { 2 - 3 } & Mean \pm SD & Mean \pm SD & \\
\cline { 1 - 2 } $\begin{array}{l}\text { Kadar Kolesterol LDL } \\
(\mathbf{m g} / \mathbf{d l})\end{array}$ & & & \\
Sebelum & $49.93 \pm 20.21$ & $50.99 \pm 16.13$ & \\
Sesudah & $50.01 \pm 4.75$ & $54.98 \pm 18.56$ & \\
$\boldsymbol{\Delta}$ & $0.08 \pm 21.94$ & $3.98 \pm 25.12$ & \multirow{2}{*}{$0.423^{\mathrm{b}}$} \\
$\mathbf{P}$ & $0.994^{\mathrm{a}}$ & $0.714^{\mathrm{a}}$ & \\
\hline Keterangan: ${ }^{a}$ Uji paired t-test & ${ }^{b}$ Uji Mann Whitney & &
\end{tabular}

Tabel 4 menunjukkan bahwa sebelum dan sesudah pemberian pakan tinggi lemak pada kelompok kontrol dan perlakuan terdapat peningkatan kadar kolesterol LDL namun tidak signifikan ( $p>0.05)$. Rerata perubahan kadar kolesterol LDL antar kelompok sebelum dan sesudah pemberian pakan tinggi lemak menunjukkan tidak terdapat perbedaan perubahan kadar kolesterol LDL antara kelompok kontrol dan perlakuan $(\mathrm{p}>0.05)$.

Perubahan Kadar Kolesterol LDL Sebelum dan Sesudah Pemberian Jus Daun Ubi Jalar

Perubahan kadar kolesterol LDL sebelum dan sesudah pemberian jus daun ubi jalar masingmasing tikus dapat dilihat pada tabel 5 .

Tabel 5. Perubahan Kadar Kolesterol LDL Sebelum dan Sesudah Pemberian Jus Daun Ubi Jalar

\begin{tabular}{cccc}
\hline Tikus & Kolesterol LDL PTL (mg/d) & Kolesterol LDL JDUJ $(\mathbf{m g} / \mathbf{d l})$ & Ket $(\boldsymbol{\Delta})$ \\
\hline \hline K1 & 58.20 & 50.68 & turun \\
K2 & 47.97 & 67.41 & naik \\
K3 & 43.70 & 67.06 & naik \\
K4 & 49.76 & 57.63 & naik \\
\hline
\end{tabular}




\begin{tabular}{llcc}
\hline K5 & 49.32 & 54.49 & naik \\
K6 & 51.08 & 31.50 & turun \\
P1 & 48.77 & 59.20 & naik \\
P2 & 67.70 & 63.63 & turun \\
P3 & 80.01 & 60.32 & turun \\
P4 & 50.26 & 57.47 & naik \\
P5 & 25.53 & 8.48 & turun \\
P6 & 57.56 & 48.07 & turun \\
\hline
\end{tabular}

Keterangan: $\quad \mathrm{K}=$ Kontrol $\quad \mathrm{P}=$ Perlakuan

Tabel 5 menunjukkan pada kelompok kontrol yang diberi pakan standar, sebanyak 2 tikus (K1, K6) menunjukkan penurunan kadar kolesterol LDL sedangkan 4 tikus (K2, K3, K4, K5) mengalami peningkatan kadar kolesterol LDL. Pada kelompok perlakuan setelah pemberian jus daun ubi jalar, sebanyak 4 tikus (P2, P3, P5, P6) menunjukkan penurunan kadar kolesterol LDL dan 2 tikus (P1, P4) mengalami peningkatan kadar kolesterol LDL. Rerata kadar kolesterol LDL kedua kelompok sebelum dan sesudah pemberian jus daun ubi jalar dapat dilihat pada tabel 6 .

Tabel 6. Rata-rata Kadar Kolesterol LDL Sebelum dan Sesudah Pemberian Jus Daun Ubi Jalar selama 14 hari

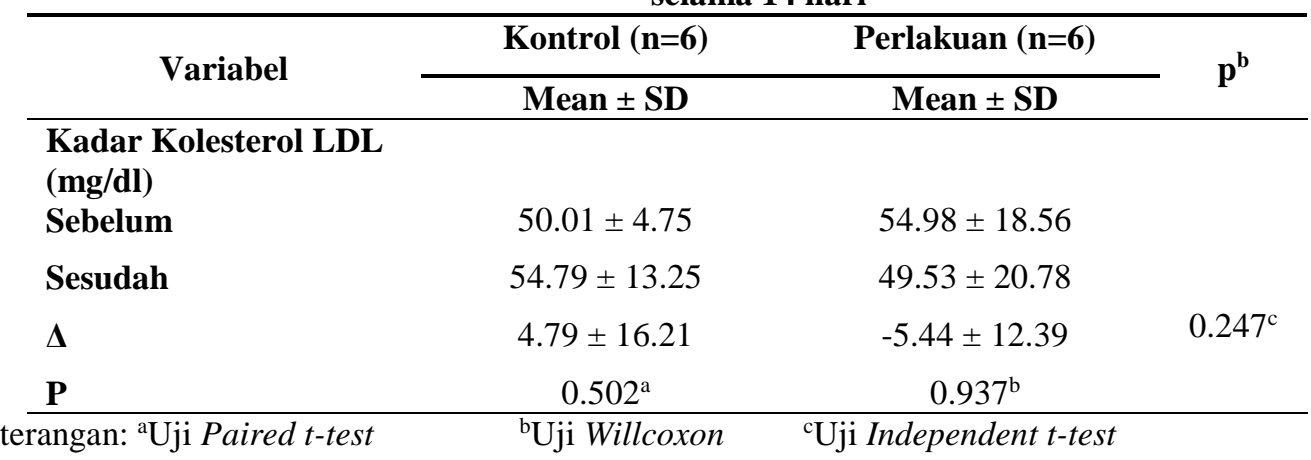

Tabel 6 menunjukkan bahwa pada kelompok kontrol sebelum dan sesudah pemberian jus daun ubi jalar terdapat peningkatan kadar kolesterol LDL namun tidak signifikan $(p>0,05)$ dan pada kelompok perlakuan terdapat penurunan kadar kolesterol LDL namun tidak signifikan ( $>0,05)$. Rerata perubahan kadar kolesterol LDL antar kelompok sebelum dan sesudah pemberian jus daun ubi jalar menunjukkan tidak terdapat perbedaan perubahan kadar kolesterol LDL antara kelompok kontrol dan perlakuan $(\mathrm{p}>0.05)$.

\section{PEMBAHASAN}

\section{Berat Badan Subjek}

Penimbangan berat badan tikus wistar dilakukan setiap minggu sekali untuk memantau kondisi tikus dan digunakan untuk penentuan jumlah pemberian pakan standar dan dosis jus daun ubi jalar pada tikus. Pada tabel 1 dan 2, rerata berat badan selama intervensi pada kelompok kontrol mengalami penurunan sedangkan kelompok perlakuan mengalami peningkatan. Penurunan berat badan tikus pada kelompok kontrol, kemungkinan disebabkan tikus mengalami stres. Penurunan berat badan sejalan dengan peningkatan kadar hormon kortikosteron yang merombak cadangan glukosa dan lemak untuk penyediaan sumber energi metabolisme yang digunakan dalam merespon stres sehingga terjadilah penurunan berat badan pada tikus. ${ }^{19}$

Peningkatan berat badan tikus pada kelompok perlakuan, sesuai dengan penelitian yang menyatakan bahwa pemberian pakan tinggi lemak dapat meningkatkan perkembangan berat badan tikus. ${ }^{20}$ Peningkatan berat badan juga dapat disebabkan oleh kandungan protein yang terdapat dalam jus daun ubi jalar. Berdasarkan penelitian, daun ubi jalar mengandung protein yang lebih tinggi dibandingkan dengan bagian umbi dan akarnya. Protein berperan penting dalam pertumbuhan dan pemeliharaan jaringan tubuh, juga sebagai sumber energi manusia dan hewan, sehingga kemungkinan dapat meningkatkan status gizi tikus dengan peningkatan berat badan. ${ }^{21}$ Pada suatu penelitian, peningkatan berat badan berpengaruh terhadap peningkatan kadar kolesterol LDL setelah pakan tinggi lemak. ${ }^{22}$

Perubahan Kadar Kolesterol LDL Sesudah Pemberian Pakan Tinggi Lemak

Pemberian pakan tinggi lemak berupa kuning telur bebek sebanyak $2 \mathrm{ml} / 200 \mathrm{gBB} /$ hari dikocok dan diinduksi ke tikus dengan cara di 
sonde. Sebanyak 100 gram kuning telur bebek mengandung 17 gram protein, 35 gram lemak, dan $884 \mathrm{mg}$ kolesterol sehingga diharapkan mampu meningkatkan kadar kolesterol LDL. ${ }^{14}$ Kolesterol secara normal diproduksi oleh tubuh dalam jumlah yang sesuai. Pola makan yang cenderung tinggi lemak jenuh dapat menyebabkan kolesterol dalam jumlah berlebihan dalam darah. ${ }^{23}$

Pada tabel 3 setelah pemberian pakan tinggi lemak sebanyak 8 tikus menunjukkan peningkatan kadar kolesterol LDL. Berdasarkan penelitian, pemberian pakan kuning telur bebek sebanyak 2 $\mathrm{ml} / 200 \mathrm{~g} / \mathrm{hari}$ dapat meningkatkan kadar kolesterol LDL, ${ }^{15}$ namun dalam penelitian ini kuning telur bebek hanya dapat meningkatkan kadar kolesterol LDL beberapa tikus wistar. Kuning telur mengandung lemak jenuh yang merupakan prekusor dari kolesterol. Mengkonsumsi lemak jenuh dapat menyebabkan peningkatan kadar kolesterol LDL. ${ }^{24}$ Sebanyak 4 tikus menunjukkan penurunan kadar kolesterol LDL, kemungkinan hal ini disebabkan oleh waktu pemberian pakan tinggi lemak yang kurang lama. Berdasarkan penelitian, diperlukan waktu empat hingga delapan minggu pemberian kuning telur agar dapat meningkatkan kadar kolesterol LDL tikus secara signifikan. ${ }^{25}$ Kemungkinan, penurunan kadar kolesterol LDL juga dapat terjadi karena penggunaan kolesterol untuk sintesis senyawa steroid yang lain, seperti hormon atau asam empedu dalam hati. ${ }^{24}$

Pada tabel 4 menunjukkan rerata kadar kolesterol LDL pada kelompok kontrol mengalami peningkatan sebesar $0,08 \mathrm{mg} / \mathrm{dl}$ sedangkan pada kelompok perlakuan mengalami peningkatan sebesar 3,98 mg/dl. Perbedaan hasil kadar kolesterol LDL sesudah pemberian pakan tinggi lemak, kemungkinan dipengaruhi oleh berbagai faktor seperti kondisi biologis dan metabolisme tubuh tikus wistar. ${ }^{26}$ Kemungkinan faktor stres pada hewan coba juga dapat disebabkan karena perlakuan saat penelitian seperti cara pemegangan, pengambilan darah, proses penyondean dan pengandangan individu. ${ }^{27}$ Ketika proses pengambilan darah melalui pleksus retroorbitalis melalui mata, beberapa tikus mengalami kerusakan mata dikarenakan pemasangan alat untuk mengambil darah tidak benar dan gerakan tikus yang aktif yang menyebabkan alat terlepas sehingga menyebabkan kerusakan mata pada tikus. Hal ini dapat menyebabkan stres pada tikus sehingga mempengaruhi kadar kolesterol LDL tikus.

Perubahan Kadar Kolesterol LDL Sesudah Pemberian Jus Daun Ubi Jalar
Pemberian jus daun ubi jalar sebanyak $0.006 \mathrm{ml} / \mathrm{gBB} /$ hari diinduksi ke tikus dengan cara di sonde. Kandungan setiap 100 gram daun ubi jalar terdapat kapasitas antioksidan sebanyak $650 \mathrm{mg}$, polifenol total sebanyak $270 \mathrm{mg}$ dan beta karoten sebanyak $13 \mathrm{mg} .{ }^{28}$ Setelah dilakukan analisis, diperoleh hasil dalam $100 \mathrm{ml}$ jus daun ubi jalar mengandung sebanyak $32,296 \mathrm{mg}$ quercetin sehingga diharapkan mampu menurunkan kadar kolesterol LDL.

Tabel 5 menunjukkan pada kelompok kontrol yang diberi pakan standar, sebanyak 2 tikus mengalami penurunan kadar kolesterol LDL. Pada kelompok perlakuan jus daun ubi jalar sebanyak 4 tikus mengalami penurunan kadar kolesterol LDL. Hal ini disebabkan karena kandungan lemak pada pakan standar dan jus daun ubi jalar lebih rendah daripada lemak pada kuning telur sehingga dapat menyebabkan penurunan kadar kolesterol LDL. Kandungan quercetin dalam jus daun ubi jalar juga dapat menurunkan kadar kolesterol LDL. Pada 4 tikus kontrol dan 2 tikus perlakuan menunjukkan peningkatan kadar kolesterol LDL, hal ini tidak sesuai dengan teori yang seharusnya kadar kolesterol LDL mengalami penurunan setelah pemberian pakan tinggi standar dan pemberian jus daun ubi jalar. Hasil uji laboratorium kadar kolesterol LDL yang tidak sesuai diduga disebabkan oleh lama waktu penyimpanan serum darah tikus sehingga menyebabkan sel - sel darah menjadi lisis. Kesalahan teknis pada saat membawa serum darah dari tempat penyimpanan ke tempat pengujian, cara pengambilan darah yang kurang tepat, cara memasukkan sampel darah ke dalam tabung yang kurang tepat juga dapat berpengaruh terhadap nilai kadar kolesterol LDL. ${ }^{29}$

Tabel 6 menunjukkan rerata kadar kolesterol LDL pada kelompok kontrol terjadi peningkatan kadar kolesterol LDL sebesar 4,79 $\mathrm{mg} / \mathrm{dL}$ sedangkan pada kelompok perlakuan menunjukkan penurunan kadar kolesterol LDL namun tidak signifikan yaitu sebesar $5,44 \mathrm{mg} / \mathrm{dL}$. Hal ini mungkin disebabkan oleh kurangnya waktu intervensi jus daun ubi jalar sehingga antioksidan dan serat yang terkandung dalam daun ubi jalar tidak dapat mengikat semua kolesterol dan lemak dalam usus. Akibatnya kolesterol dan lemak dapat diserap oleh alat pencernaan hewan uji. ${ }^{30}$ Penurunan kadar kolesterol LDL juga dapat disebabkan karena pada daun ubi jalar mengandung flavonoid jenis quercetin yang berperan dalam menghambat oksidasi LDL dan mencegah terjadinya radikal bebas. LDL yang bersifat aterogenik adalah LDL teroksidasi. Fungsi utama LDL adalah mengangkut 
asam lemak tak jenuh, vitamin yang larut dalam lemak dan kolesterol yang membutuhkannya. Selama perjalanannya, LDL mengalami oksidasi dengan hasil metabolik yang bermacam-macam. Jika LDL ada dalam jumlah banyak dalam pembuluh darah, oksidasi LDL ini akan dijumpai dalam jumlah yang banyak pula dalam dalam darah. Oksidasi LDL berbahaya bagi endotel karena akan merangsang pengeluaran molekul adhesi dan zat kemoatraktan sehingga menyebabkan disfungsi endotel. Quercetin berperan sebagai antihistamin dan antiinflamasi. Quercetin juga merupakan antioksidan yang dapat menangkap partikel-partikel radikal bebas dalam tubuh. Radikal bebas dapat merusak membran sel, serta berkaitan dengan proses aterogenesis yang mengarah pada penyakit kardiovaskular. ${ }^{31}$ Berdasarkan penelitian, pemberian quercetin murni pada dosis $2 \mathrm{mg} / \mathrm{kgBB}$ dapat menurunkan kadar Adipocyte-Fatty Acid Binding Protein (A-FABP). A-FABP merupakan suatu protein intrasel pengikat asam lemak yang diekspresikan di dalam adiposit (sel lemak) dan berfungsi sebagai regulator fungsi biologis adiposit. A-FABP ditemukan dalam sirkulasi (terutama serum) dan berasosiasi kuat dengan kejadian sindrom metabolik, sehingga A-FABP dapat digunakan sebagai penanda sindrom metabolik. Beberapa penelitian menunjukkan bahwa oksidasi LDL dapat memodulasi munculnya A-FABP ini. ${ }^{9}$ Oksidasi kolesterol LDL merupakan suatu proses biologi yang diduga terlibat dalam mekanisme proses inisiasi dan akselerasi lesi arteri. LDL yang teroksidasi dapat menyebabkan viskositas darah menjadi lebih kental dan peluang terjadinya penyumbatan pembuluh darah (aterosklerosis) menjadi lebih tinggi. Dengan adanya senyawa antioksidan maka oksidasi LDL dapat dihindari. ${ }^{32}$

\section{SIMPULAN DAN SARAN}

Pemberian jus daun ubi jalar (Ipomoea batatas (L.) Lam) sebanyak $0,006 \mathrm{ml} / \mathrm{gBB} /$ hari selama 14 hari tidak dapat menurunkan kadar kolesterol LDL tikus Wistar jantan (Rattus norvegicus) yang diberi pakan tinggi lemak. Perlu melakukan uji kandungan jus daun ubi jalar untuk mengetahui kandungan zat gizi, antinutrisi, dan fitokimia secara keseluruhan dan uji kandungan telur bebek untuk mengetahui kandungan lemak dan kolesterol secara keseluruhan yang digunakan dalam penelitian, perlu penelitian lebih lanjut mengenai dosis yang bervariasi, waktu penelitian yang panjang serta perlu penelitian pada manusia untuk mengetahui keefektifan pemberian jus daun ubi jalar dalam penurunan kadar kolesterol LDL pada manusia.

\section{DAFTAR PUSTAKA}

1. Sumardika IW, Jawi IM. Ekstrak Air Daun Ubi Jalar Ungu dalam Memperbaiki Profil Lipid dan Meningkatkan Kadar SOD Darah Tikus yang Diberi Makanan Tinggi Kolesterol. Fakultas Kedokteran Universitas Udayana. Jurnal Ilmiah Kedokteran. Medicina. Volume 43 Nomor 2. Mei 2012)

2. Bambang P, Eriza F, Adina N. Efek Pemberian Jus Terong Ungu (Solanum melogena L.) terhadap Kadar LDL Tikus Putih (Rattus novergicus strain Wistar) yang Diberi Diet Aterogenik. Program Studi Ilmu Gizi Fakultas Kedokteran Universitas Brawijaya. 2013.)

3. Direktorat Bina Farmasi Komunitas dan Klinik Ditjen Bina Kefarmasian dan Alat Kesehatan Departemen Kesehatan. Pharmaceutical Care untuk Pasien Penyakit Jantung Koroner: Fokus Sindrom Koroner Akut. Jakarta: 2006

4. Dinas Kesehatan Provinsi Jawa Tengah. Buku Profil Kesehatan Provinsi Jawa Tengah Tahun 2012. Available on www.dinkesjatengprov.go.id

5. Salim AY, Anjar N. Hubungan Olahraga dan Penyakit Jantung Koroner di RSUD Dr. Moewardi. Sekolah Tinggi Ilmu Kesehatan (STIKES) 'Aisyiyah Surakarta. 2013)

6. Islam S. Nutritional and Medicinal Qualities of Sweetpotato Tops and Leaves. University of Arkansas at Pine Bluff. 2006.

7. Rizna TR. Efek Propolis terhadap Kadar Kolesterol Total pada Tikus Model Tinggi Lemak. Bagian Anatomi, Fakultas Kedokteran, Universitas Kristen Maranatha. Bandung. JKM. Vol.11 No.1 Juli 2011:17-22

8. Carey EE, Oyunga MA, K'osambo L, Smit NEJM, p'Obwoya CO, Turyamureeba G, et al. Using orange-fleshed sweetpotato varieties to combat vitamin A deficiency and enhance market opportunities for smallholder farmers in subSaharan Africa. International Potato Center (CIP), Sub-Saharan Africa Region, P.O. Box 25171, Nairobi, Kenya

9. Sudiarto, Setyawati SK, dan Shinta FN. The Effect of Quercetin on Adipocyte-Fatty Acid Binding Protein Level. Jurnal Kedokteran Brawijaya; 2010; 26(1).

10. Pitoyo FLH dan Heni Fatmawati. The Effect Quercetin to Reduce Trigliceride and Blood Glucose Level in Animal Model Diet - Induced Obesity. Jurnal Medika Planta; 2012; 1(5).

11. Perdido. Efek Pemberian Jus Avokad (Persea Americanana P.Mill) terhadap Kadar Kolesterol HDL dan LDL Tikus Putih (Rattus Norvegicus). Fakultas Kedokteran Universitas Sebelas Maret. Surakarta. 2011

12. World Health Organization (WHO). General Guidelinesfor Methodologies on Research and 
Evaluation of Traditional Medicine. Geneva: WHO; 2001.

13. Riyantie, Novie. Pengaruh Defisiensi Pakan terhadap Perubahan Beberapa Berat Organ Tikus Betina Dewasa (Rattus sp.). Bagian Fisiologi dan Farmakologi. Fakultas Kedokteran Hewan. Institut Pertanian Bogor. 2001.

14. Sumber data: Badan Ketahanan Pangan dan Penyuluhan Provinsi DIY

15. Kahono JY. Pengaruh Ekstrak Herba Meniran (Phyllantus niruri L.) terhadap Kadar Trigliserida Darah Tikus Putih (Rattus norvegicus). Universitas Sebelas Maret. 2010

16. Ghasemzadeh Ali, Hawa ZEJ, dan Asmah R. Antioxidant Activities, Total Phenolics and Flavonoids Content in Two Varieties of Malaysia Young Ginger (Zingiber officinale Roscoe). Molecules; 2010; 15: 4324-33.

17. Foltress Diagnostic. LDL Cholesterol. Available from URL: http://www.fortressdiagnostics.com/online/ifu/BX C0432A.pdf

18. Dahlan MS. Statistik untuk Kedokteran dan Kesehatan. Salemba Medika. Jakarta: 2011.

19. Ridwan A, Zakaria Z, Barlian A. Pengaruh Fotoperiode terhadap Respon Stres dan Parameter Reproduksi pada Mencit Jantan (Mus musculus L.) Galur Swiss Webster. Institut Tekhnologi Bandung. Jurnal Matematika \& Sains, April 2012, Vol. 17 Nomor 1

20. Fatimah F, Rindengan B. Pengaruh Diet Emulsi Virgin Coconut Oil (VCO) terhadap Profil Lipid Tikus Putih (Rattus norvegicus). Universitas Sam Ratulangi Manado. Jurnal Littri 17(1), Maret 2011. Hlm. $18-24$

21. Asmara IY, Garnida D, dan Tanwiriah W. Penampilan Broiler yang Diberi Ransum Mengandung Tepung Daun Ubi Jalar (Ipomoea batatas) terhadap Karakteristik Karkas. Fakultas Peternakan Universitas Padjadjaran Bandung. J.Indon.Trop.Anim.Agric. 12632 [2] June 2007

22. Jia YJ, Liu J, Guo YL, Xu RX, Sun J, LI JJ. Dyslipidemia in rat fed with high-fat diet is not associated with PCSK9-LDL receptor pathway but ageing. Chinese Academy of Medical Sciences, Peking Union Medical College. Beijing, China. Journal of Geriatric Cardiology (2013) 10: 361-368

23. Cynthia, Novi. Pengaruh Pemberian Ekstrak Kacang Hijau (Phaseolus radiatus) terhadap Kadar Kolesterol LDL Serum Tikus Hiperkolesterolemia. Universitas Diponegoro. 2013

24. Harini M. Kadar Kolesterol Darah Dan Ekspresi VCAM-1 Pada Endotel Aorta Tikus Putih ( Rattus norvegicus L) Hiperkolesterolemik Setelah Perlakuan VCO. Pascasarjana Program Studi Biosains Universitas Sebelas Maret Surakarta. 2009

25. Dwiloka B. Efek Kolesterolemik Berbagai Telur. Media Gizi dan Keluarga, Desember 2003, 27 (2): 58-65
26. Widyaningsih W. Efek Ekstrak Etanol Rimpang Temugiring (Curcuma heyneana val) terhadap Kadar Trigliserida. Fakultas Farmasi Universitas Ahmad Dahlan Yogyakarta. Jurnal Ilmiah Kefarmasian, Vol. 1, No. 1, $2011: 55-65$

27. Balcombe, JP., Bernard, ND., et al. Laboratory Rountines Cause Animal Stress. American Association for Laboratory Animal Science;2004: 43;6

28. Lako J, V. Craige T, Mark W, Naiyana W, Subramanium S, Robert P. Phytochemical flavonols, carotenoids and the antioxidant properties of a wide selection of Fijian fruit, vegetables and other readily available foods. Monash University. Australia. 2007

29. Harahap Dianatul Habibah, Yudha Fahrimal, dan Hamdani Budiman. Gambaran Darah Tikus yang diinfeksikan Trypanosoma evansi dan diberi Ekstrak Daun Sernai (Wedelia biflora). Jurnal Medika veterinaria, 2013:7(2);126-9.

30. Juheini. Pemanfaatan Herba Seledri (Apium graveolens L.) untuk Menurunkan Kolesterol dan Lipid dalam Darah Tikus Putih yang Diberi Diit Tinggi Kolesterol dan Lemak. Jurusan Farmasi, Fakultas Matematika dan Ilmu Pengetahuan Alam, Universitas Indonesia. Makara, Sains, Vol. 6, No. 2, Agustus 2002)

31. Brata HW. Hubungan Pola Makan, Obesitas, Keteraturan Berolahraga dan Kebiasaan Merokok dengan kejadian Hiperkolesterolemia. Semarang: Universitas Muhammadiyah Semarang. 2009.

32. Chuang LT, Robert HG, Yuan CW, Pei WY, Chih CL, Jack MP, et al. Comparison of the Fatty Acid, Amino Acid, Mineral and Antiosidant Content of Sweet Potato Leaves Grown on Matsu Island and Mainland Taiwan. Global Sience Books. 2011;5 (1):43-7. 